Review

\title{
Physical and Biological Treatment Technologies of Slaughterhouse Wastewater: A Review
}

\author{
Mohammed Ali Musa ${ }^{1,2}$ and Syazwani Idrus ${ }^{1, *(D)}$ \\ 1 Department of Civil Engineering, Faculty of Engineering, Universiti Putra Malaysia, \\ Serdang 43400, Selangor, Malaysia; alisulezee@gmail.com \\ 2 Department of Civil and Water Resources Engineering, University of Maiduguri, \\ Maiduguri P.M.B. 1069, Borno State, Nigeria \\ * Correspondence: syazwani@upm.edu.my; Tel.: +60-13-692-2301
}

Citation: Musa, M.A.; Idrus, S. Physical and Biological Treatment Technologies of Slaughterhouse Wastewater: A Review. Sustainability 2021, 13, 4656. https://doi.org/ $10.3390 /$ su13094656

Academic Editor: Haoran Duan

Received: 13 February 2021

Accepted: 25 March 2021

Published: 22 April 2021

Publisher's Note: MDPI stays neutral with regard to jurisdictional claims in published maps and institutional affiliations.

Copyright: (C) 2021 by the authors Licensee MDPI, Basel, Switzerland. This article is an open access article distributed under the terms and conditions of the Creative Commons Attribution (CC BY) license (https:// creativecommons.org/licenses/by/ $4.0 /)$.

\begin{abstract}
Physical and biological treatment technology are considered a highly feasible and economic way to treat slaughterhouse wastewater. To achieve the desired effluent quality for disposal or reuse, various technological options were reviewed. However, most practical operations are accompanied by several advantages and disadvantages. Nevertheless, due to the presence of biodegradable organic matter in slaughterhouse waste, anaerobic digestion technology is commonly applied for economic gain. In this paper, the common technologies used for slaughterhouse wastewater treatment and their suitability were reviewed. The advantages and disadvantages of the different processes were evaluated. Physical treatments (dissolved air floatation (DAF), coagulation-flocculation and sedimentation, electrocoagulation process and membrane technology) were found to be more effective but required a large space to operate and intensive capital investment. However, some biological treatments such as anaerobic, facultative lagoons, activated sludge process and trickling filters were also effective but required longer start-up periods. This review further explores the various strategies being used in the treatment of other wastewater for the production of valuable by-products through anaerobic digestion.
\end{abstract}

Keywords: wastewater; slaughterhouse wastewater; physical treatment; biological treatment

\section{Introduction}

The effective treatment of high-strength industrial wastewater has increased over time due to the effects related to environmental pollution. The discharge of untreated slaughterhouse wastewater (SWW) constitutes a severe threat to public health and the environment [1]. Although rivers have a natural cleansing capacity, the frequent release of such effluent without it being adequately treated first might overburden the receiving water body. Today, the management of wastewater needs to incorporate both waste minimization and resource recovery [2]. Although fresh water consumption by different slaughterhouse industry varies in magnitude and concentration, it is usually preferable to minimize wastewater generation at its source. The wastewater generated from a slaughterhouse consists of organic by-products which are considered industrial organic wastes, which are challenging to treat due to their high protein and lipid contents. The main organic streams that portrayed SWW as recalcitrant in nature include the blood, paunches from the removal of the rumen and the intestinal content, the intestinal residues from the evisceration process [3], fats from the meat trim step as well as the head and the limbs (mostly bones). Conventionally, SWW treatment methods are similar to the current technologies used in municipal wastewater treatment, which include physicochemical and biological treatments where each method has its advantages and disadvantages. 


\subsection{Physicochemical Treatment}

Physicochemical treatment methods usually involve solid separation from the fluid. It is recommended that the effluent be sent for primary or secondary treatment after the preliminary treatment depending on the intensity of the SWW [4]. Dissolved air floatation (DAF), coagulation-flocculation and sedimentation, electrocoagulation process and membrane technology are usually employed as primary treatment technologies for the treatment of SWW $[5,6]$. In the analysis of samples, the standard methods for the examination of water and wastewater of the American Public Health Association [7] are commonly applied, to achieve chemical oxygen demand (COD), biochemical oxygen demand (BOD), total suspended solid (TSS), volatile suspended solids (VSS), ammonia nitrogen $\left(\mathrm{NH}_{3}-\mathrm{N}\right)$, fats, oil and grease (FOG), colour and turbidity removals.

\subsubsection{Dissolved Air Floatation (DAF)}

Dissolved air floatation is simply the introduction of air from the bottom of the system for liquid-solid separation, as shown in Figure 1. During operation, the FOG light solid materials are transported to the surface, creating a sludge blanket. Thus, the scum formed is continuously removed by scrapping.

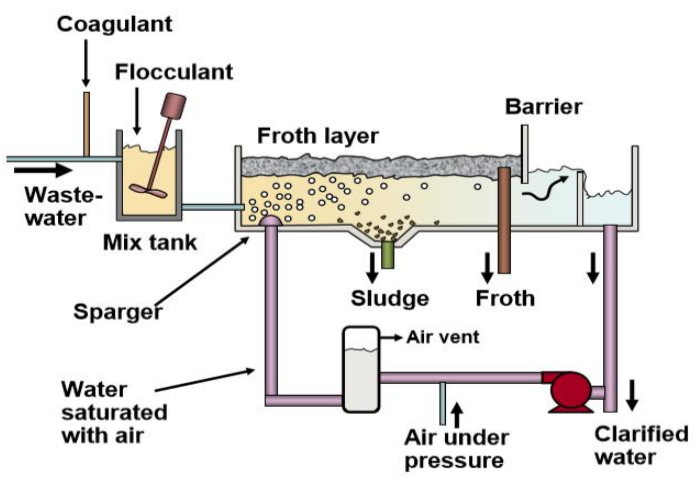

Figure 1. Schematic diagram of the dissolved air floatation clarifier unit [8].

Polymers and other flocculants are usually applied to enhance the efficiency of DAF. In treating SWW, ferric chloride and aluminium sulphate are usually added to facilitate the aggregation and precipitation of protein in addition to fat and grease floatation. Moreover, 30 to $90 \%$ COD, as well as 70 to $80 \%$ BOD removal efficiency can be achieved using the DAF process. Furthermore, Mittal. [9] and De Nardi et al. [5] have shown that the DAF system is capable of achieving moderate to high nutrient removal. Floatation can also be used as an alternative method of handling pulp and paper mill effluent in addition to firm settling. These devices inject a pressurized flow of air-saturated water at the base of a deep chest that holds the paper mill process steam.

The injected water s released into the chest, and tiny air bubbles come out of the solution and start to rise. The rising bubbles tend to carry any other fairly solid binding particles and can easily be skimmed from the water's surface. DAF's main drawback, however, is commonly associated with relatively frequent system failure and inefficient TSS separation [10]. Therefore, an alternative treatment system like the upflow anaerobic sludge blanket reactor is required, due to its lesser energy demand, smaller ecological foot print production as well as its overall operation and maintenance cost.

\subsubsection{Coagulation-Flocculation and Sedimentation}

The addition of coagulant into a reactor vessel containing SWW promotes the formation of large colloidal particles, which are called flocs. The colloidal particles produced in SWW, however, are negatively charged, making them stable and aggregation resistant. Coagulants with positively charged ions are therefore added into the vessel for proper floc formation in order to destabilize the colloidal particles to form flocs and ease the 
sedimentation process. Chemicals such as ferric chloride, ferric sulphate, aluminium sulphate, aluminium chlorohydrate, and poly-aluminium chloride were used as coagulants for the SWW treatment. The use of poly-aluminium chloride as reagent showed a total phosphorus (TP), total nitrogen (TN), and COD removals efficiencies of up to $99.9 \%, 88.8 \%$, and $75.0 \%$, respectively. On the other hand, the sludge volume can be reduced by $41.6 \%$ using inorganic coagulants $[9,11]$. Figure 2 demonstrates coagulation-flocculation and sedimentation processes.

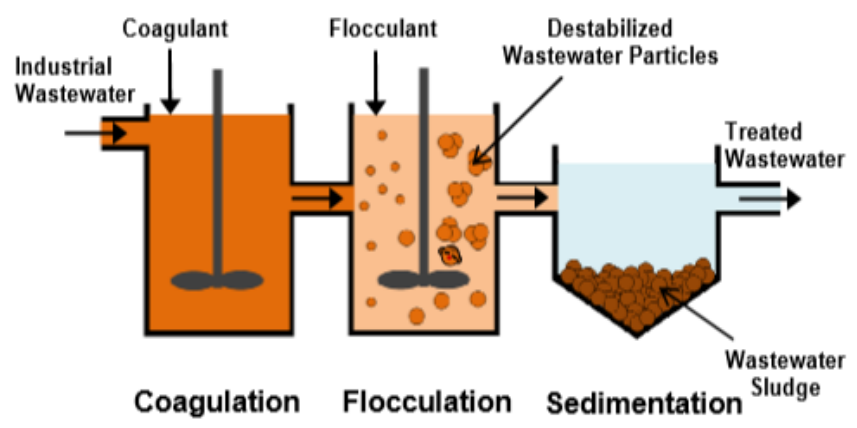

Figure 2. Schematic representation of coagulation-flocculation processes [12].

Satyanarayan et al. [13] have reported the use of anionic polyelectrolyte, ferrous sulphate, lime, and alum as coagulants in the treatment of SWW. The results revealed BOD, COD, and TSS removal efficiencies of $38.9,36.1$, and $41.9 \%$ using only lime as a coagulant. A significant improvement in COD removal up to $56.8 \%$ was realized in the combination of ferrous sulphate with lime. Likewise, an increase in COD removal to $42.6 \%$ was recorded in the combination of alum and lime. Tariq et al. [14] investigated the use of alum and lime individually in the treatment of SWW. It was revealed that with the increasing dose of alum, the COD removal reached a maximum of $92 \%$ along with high sludge volume, and this rendered the process inefficient. Conversely, $74 \%$ COD reduction was realized with an increasing dosage of lime as a single coagulant. Comparatively, the sludge volume generated using lime was quite low compared to that of alum. However, the combination of the two coagulants revealed a maximum COD removal of $85 \%$ with a small quantity of sludge volume.

Different contaminants can be removed from the wastewater through coagulation/ flocculation which would otherwise be difficult without the application of these chemicals. Limited investment is required for these tanks and dosing units. Nevertheless, the operating costs are a major disadvantage of this strategy. In some situations, significant amounts of coagulant and flocculent are needed to achieve the required level of flocculation. A certain amount of physico-chemical sludge is also produced, which is usually handled externally. These costs may escalate, especially with large volumes of wastewater. The correct dosage of chemicals is also very important for the proper functioning of the process. Therefore, this is not simple for sewage with widely varying composition.

\subsubsection{Electrocoagulation (EC) Process}

Electrocoagulation requires the production of in situ coagulants by electrically dissolving aluminium or iron from aluminium or iron electrodes, respectively. Figure 3 shows the schematic diagram of electrocoagulation processes. Metal ions are produced at the anode and hydrogen gas is emitted from the cathode. Hydrogen gas would also help lift the flocculated particles out of the air. The electrodes can be set in a monopoly or bipolar mode. The products may be made of aluminium or iron in the form of plates or the form of scraps, such as steel turning and milling. The EC process is an advanced treatment technology recently applied to the treatment of SWW. According to Emamjomeh and Sivakumar [15] and Bayar et al. [16], the system is capable of removing pathogens, organics, nutrients, and even heavy metals from SWW by introducing an electric current without the addition of any chemical. Electrodes such as $\mathrm{Al}, \mathrm{Fe}, \mathrm{Pt}, \mathrm{SnO}_{2}$, and $\mathrm{TiO}_{2}$ are commonly utilized for 
the EC process, however, $\mathrm{Al}$ and Fe are the most widely applied. In the EC process, $\mathrm{M}^{3+}$ ions are usually generated on-site with the help of sacrificial anodes. Moreover, studies have shown that these sacrificial electrodes might interact with hydrogen ions in an acidic medium or with an $\mathrm{OH}$ - ion in an alkaline medium [17-20]. For instance, the research of Kobya et al. [18] into the EC process treating SWW demonstrated that $\mathrm{Al}$, as an electrode material in the EC process, was responsible for removing up to $93 \%$ COD, whereas $\mathrm{Fe}$ as an electrode material was able to achieve a maximum of $98 \%$ oil and grease removal efficiency. During this process, the influential parameters that lead to the high COD, oil, and grease removal included the $\mathrm{pH}$, operating time, electrode material, and the current density.

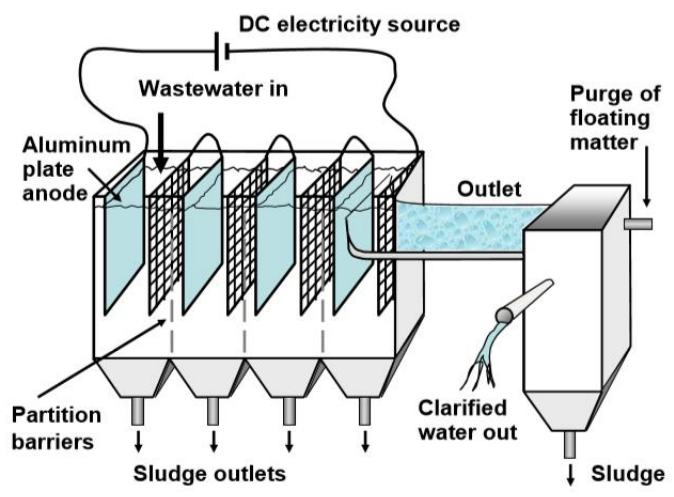

Figure 3. Schematic representation of the electrocoagulation processes [21].

An evaluation of the chemical reactions that occur in the process of electrocoagulation reveals that the main electrode reactions (aluminium electrodes) are:

$$
\begin{gathered}
\text { Anode: } \mathrm{Al} \rightarrow \mathrm{Al}^{3+}(\mathrm{aq})+3 \mathrm{e} \\
\text { Cathode: } 3 \mathrm{H}_{2} \mathrm{O}+3 \mathrm{e} \rightarrow 3 / 2 \mathrm{H}_{2}+3 \mathrm{O}^{-}
\end{gathered}
$$

The cathode may also be chemically attacked by $\mathrm{HO}^{-}$ions generated during $\mathrm{H} 2$ evolution at high $\mathrm{pH}$ [22]:

$$
2 \mathrm{Al}+6 \mathrm{H}_{2} \mathrm{O}+2 \mathrm{HO}^{-} \rightarrow 2 \mathrm{Al}(\mathrm{HO})_{4}{ }^{-}+3 \mathrm{H} 2
$$

$\mathrm{Al}^{3+}(\mathrm{aq})$ and $\mathrm{OH}^{-}$ions generated by electrode reactions (1) react to form various monomeric species such as $\mathrm{Al}(\mathrm{OH})^{2+}, \mathrm{Al}(\mathrm{HO})_{2}{ }^{+}, \mathrm{A}_{12}(\mathrm{HO})_{2}{ }^{4+}$ and $\mathrm{Al}(\mathrm{HO})_{4}{ }^{-}$, and polymeric species such as $\mathrm{Al}_{6}(\mathrm{HO})_{15}{ }^{3+}, \mathrm{A}_{17}(\mathrm{HO})_{17}{ }^{4+}, \mathrm{Al}_{8}(\mathrm{HO})_{20}{ }^{4+}$, and $\mathrm{Al}_{13} \mathrm{O}_{4}(\mathrm{HO})_{24}{ }^{7+}$, $\mathrm{Al}_{13}(\mathrm{HO})_{34}{ }^{5+}$, which finally transform into $\mathrm{Al}(\mathrm{OH})_{3}$ according to complex precipitation kinetics [23].

\subsubsection{Membrane Technology}

Membrane technology is becoming more popular in the treatment of water and wastewater due to regulatory issues towards meeting the stringent water quality requirements. Microfiltration (MF), ultrafiltration (UF), nanofiltration (NF) and reverse osmosis (OS) are the common membrane technologies used for water purification. Figure 4 depicts the different membrane sizes for the treatment of water and wastewater. Depending on the pore size, membranes can remove colloids, particles, and macromolecules. This technology is increasingly applied in the treatment of SWW to remove organic matter and bacteria [24]. The performance of RO in the treatment of secondary effluent of SWW (activated sludge as pre-treatment) was reported by Bohdziewicz and Sroka [25]. The result of parameters like BOD, COD, TN, and TP were found as 50.0, 85.8, 90.0, and 97.5\%, respectively. It was concluded that $\mathrm{RO}$ was a suitable technique for the post-treatment of SWW effluent. The study of Yordanov [26] on the performance of the UF membrane treating SWW showed 
BOD and COD removal efficiencies of around $97.8-97.89$ to $94.52-94.74 \%$, whereas TSS and FOG removal were 98 and $99 \%$, respectively.

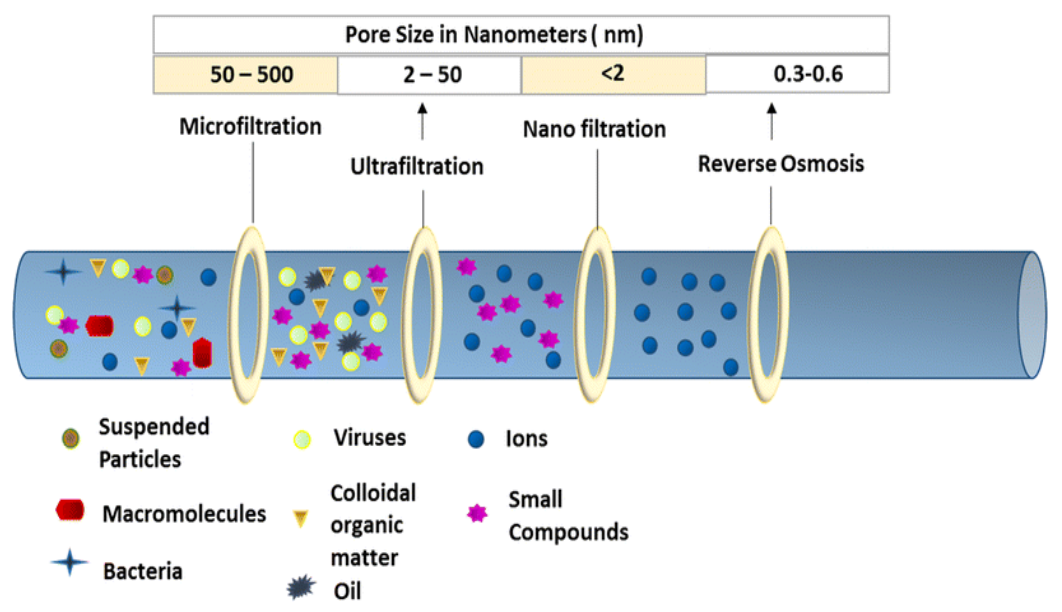

Figure 4. Schematic representation of pressure-driven membrane filtration [27].

The investigation of Gürel and Büyükgüngör [28] indicated that a membrane bioreactors could significantly remove nutrients and other organics from SWW. A pilot-scale experiment of anaerobic submerged bioreactor membrane (SAMBR) treating high-strength wastewater (raw tannery wastewater) achieved a higher COD removal efficiency of up to $90 \%$ at $6 \mathrm{~g} / \mathrm{L} \cdot$ day organic loading rate (OLR) and biogas production $(0.160 \mathrm{~L} \mathrm{~g} \mathrm{COD}$ removed) [29]. The process worked efficiently but was strongly characterized by a high hydraulic retention time (HRT) of $40 \mathrm{~h}$, and as such high energy was spent, although the permeate flux remained at (6.8 LMH) well below the critical flux (17.5 LMH) as established in the earlier work of $\mathrm{Hu}$ and Stuckey [30]. Most recently, the filtration performance of an anaerobic membrane bioreactor (AnMBR) treating high strength lipid-rich wastewater and corn-to-ethanol thin stillage was conducted by Dereli et al. [31]. The reactors delivered a high COD removal efficiency of up to $99 \%$ under stable operating conditions with an average OLR of $8.3,7.8$ and $6.1 \mathrm{~kg} \mathrm{COD} / \mathrm{m}^{3}$.day. However, the permeate turned out to be inferior in quality with an increased solid retention time (SRT). Generally, membrane lifetime remains the main concern of investors in the water treatment and wastewater industries. The efficiency of reversing fouling on the membrane surface is being exploited by physical, chemical, and biological methods. Although there were enough physical and chemical methods, the disadvantages are enormous. During aeration, much energy is expended, and sometimes chemicals are used for membrane cleaning, and this activity does not benefit the players in this field in terms of cost and environment.

\subsubsection{Summary of Physicochemical Treatment Methods}

Table 1 summarizes the advantages and disadvantages of the different physicochemical treatment methods of slaughterhouse wastewater.

Table 1. Advantages and disadvantages of physicochemical methods.

\begin{tabular}{|c|c|c|}
\hline Methods & Advantage & Disadvantage \\
\hline $\begin{array}{l}\text { Dissolved air } \\
\text { floatation }\end{array}$ & $\begin{array}{l}\text { It can achieve } 30-90 \% \text { COD and } 70-80 \% \\
\text { BOD removal efficiencies. } \\
\text { - } \quad \text { Moderate to high nutrient removal. } \\
\text { Tends to carry fairly solid binding particles } \\
\text { and can easily be skimmed from the water's } \\
\text { surface. }\end{array}$ & $\begin{array}{l}\text { - } \quad \text { High energy demand due to aeration. } \\
\text { - } \quad \text { Chemical addition which renders the sludge } \\
\text { - } \quad \text { Inefficient total suspended solid separation. } \\
\text { - } \quad \text { Lacks energy recovery facilities. } \\
\text { - } \quad \text { Frequent system failure. } \\
\text { - } \quad \text { High cost of operation and maintenance. }\end{array}$ \\
\hline
\end{tabular}


Table 1. Cont.

\begin{tabular}{|c|c|c|}
\hline Methods & Advantage & Disadvantage \\
\hline $\begin{array}{l}\text { Coagulation- } \\
\text { flocculation and } \\
\text { sedimentation }\end{array}$ & $\begin{array}{l}\text { Promotes large colloid formation which can } \\
\text { easily sediment. } \\
\text { - TP, TN, and COD removals efficiencies of up } \\
\text { to } 99.9 \%, 88.8 \% \text {, and } 75.0 \% \text { can be achieved. }\end{array}$ & 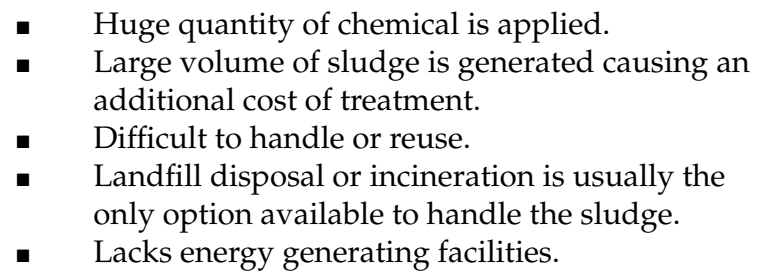 \\
\hline $\begin{array}{l}\text { Electrocoagulation } \\
\text { (EC) process }\end{array}$ & $\begin{array}{l}\text { - The system is capable of removing } \\
\text { pathogens, organics and other nutrients by } \\
\text { introducing electric current. } \\
\text { High COD and FOG removal efficiency } \\
(>90 \%) \text {. }\end{array}$ & $\begin{array}{l}\text { - High energy demand and not cost effective. } \\
\text { Lack energy generation facilities especially in the } \\
\text { treatment of organic wastewater to high energy } \\
\text { potentials. }\end{array}$ \\
\hline $\begin{array}{l}\text { Membrane } \\
\text { technology }\end{array}$ & $\begin{array}{l}\text { Depending on the type of membrane, the } \\
\text { technology is capable of achieving } \\
97.8-97.89 \% \text { and } 94.52-94.74 \% \text { BOD and } \\
\text { COD removal efficiencies in the treatment of } \\
\text { slaughterhouse wastewater. }\end{array}$ & $\begin{array}{l}\text { - Characterized by frequent fouling. } \\
\text { During aeration, much energy is expended, and } \\
\text { sometimes chemicals are used for membrane } \\
\text { cleaning. } \\
\text { - High energy input and zero energy output } \\
\text { especially in the treatment of slaughterhouse } \\
\text { wastewater. }\end{array}$ \\
\hline
\end{tabular}

\section{Biological Treatment}

In the treatment of SWW, biological treatment is applied as a secondary treatment to reduce the concentration of BOD and other soluble compounds after primary treatment [32]. Depending on the characteristics of SWW, the biological process is applied when aerobic and anaerobic digestion are operating individually or as combined systems with packing material [33]. Unlike the physicochemical process, the biological treatment process employs the use of microorganisms to remove organics from SWW effluent. Mittal [9] demonstrated that the biological method that properly applies the aerobic or anaerobic process could remove about $90 \%$ BOD from SWW effluent. There exist different biological systems, which include anaerobic, aerobic, facultative lagoons, the activated sludge process and trickling filters [34]. Generally, the mechanisms of biological treatment are a function of bacterial consortium to break down organic waste.

\subsection{Anaerobic Treatment}

Anaerobic treatment technology has proven to be a vital area of research in the management of organic waste. This is because the technology tends to offset the setbacks exhibited by aerobic and physicochemical methods [35]. Considering the portion of the industry's waste and its by-products that have recovery potential for direct reuse, including nutrients and methane gas, anaerobic systems are a suitable technology for handling high-strength industrial wastewater such as swine and SWW. It is seen in the discharged effluent consistency, material recovery, energy generation, and sludge output, handling, and storage [36]. The biogas composition consists of methane (55-70\%) and carbon dioxide (30-45\%) under strictly anaerobic conditions. Other contaminants are nitrogen (0-15\%), oxygen (0-3\%), water (1-5\%), hydrocarbons (0-200 $\left.\mathrm{mg} \mathrm{m}^{-3}\right)$, ammonia $(0-100 \mathrm{ppmv})$ and siloxane (0-41 $\left.\mathrm{mg} \mathrm{Si} \mathrm{m}^{-3}\right)$ [37]. Typical anaerobic digestion systems include anaerobic lagoon (AL), anaerobic filter (AF), anaerobic baffled reactor (ABR), and upflow anaerobic sludge blanket reactor (UASB).

\subsubsection{Anaerobic Lagoon}

Anaerobic lagoons (ALs) have been widely applied in the degradation of wastewater, especially in developing countries with hot weather. The method used largely depends on the climate, location, availability of land, and proximity to urban areas [9]. The influent is 
usually introduced through the bottom of the system and is not mechanical mixed. A layer of scum frequently forms on the surface of the lagoon, ensuring the system is confined to anaerobic conditions with low heat loss. Figure 5 showed a typical anaerobic lagoon. According to the literature [38,39], the COD, BOD, and TSS removal efficiency of a typical AL with a depth of 3-5 m and a hydraulic retention time of 5-10 days were found as $96 \%$, $97 \%$ and $95 \%$, respectively.

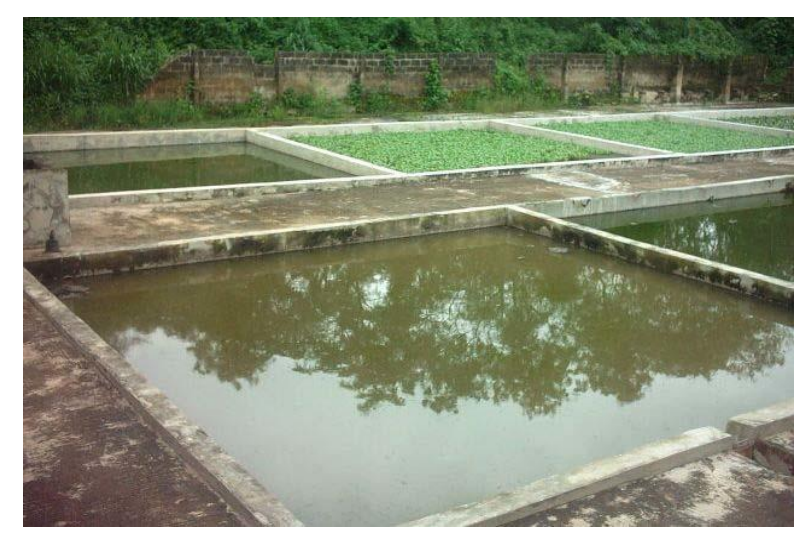

Figure 5. Anaerobic lagoon for wastewater treatment [40].

However, this system's pitfalls include odour generation and weather dependency, coupled with a long HRT and requiring a large area of land to operate. Thus, to reduce odour and smell, the synthetic floating cover is normally employed to collect biogas and trap the odour, as shown in Figure 6.

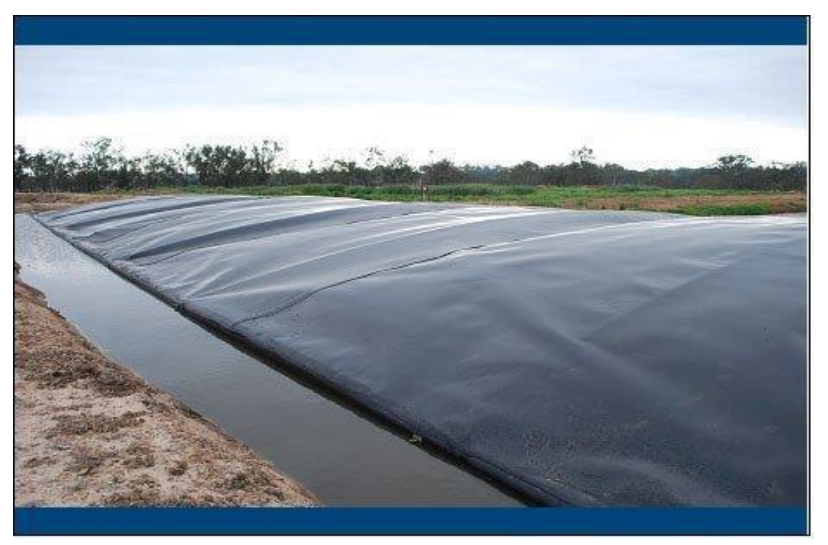

Figure 6. Anaerobic lagoon with cover [41].

Moreover, the synthetic cover must be durable and able to resist change in temperature, or ice and snow accumulation [9]. ALs are frequently the preferred method of treating SWW due to their simplicity as well as their low operational and maintenance costs, especially in developing countries [39].

\subsubsection{Anaerobic Filters}

Anaerobic filters are usually run in upflow mode, as the system has a lower risk of washing out the fixed biomass, as shown in Figure 7. 


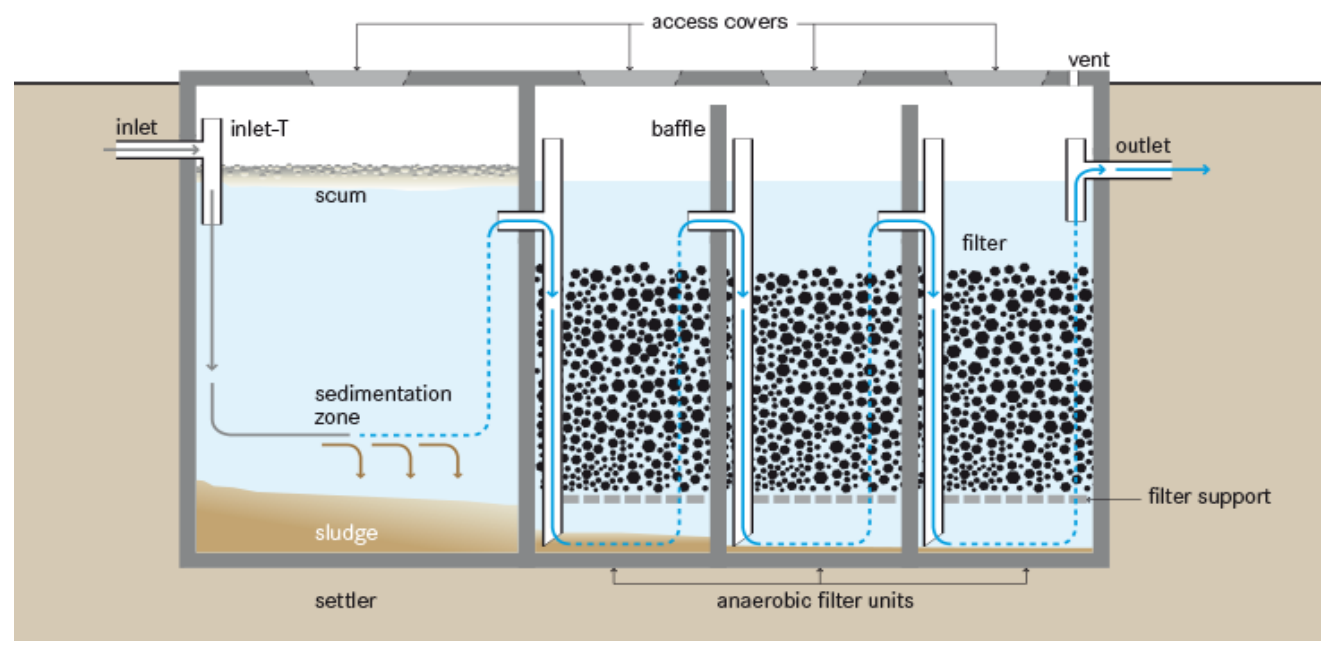

Figure 7. Anaerobic filter for wastewater treatment [42].

In order to ensure an even flow regime, the water level must cover the filter media by at least $0.3 \mathrm{~m}$. Hydraulic retention time (HRT) is the most important design parameter to influence filter efficiency. For bacteria to grow, the ideal filter should have a large area, with pores small enough to avoid clogging. The surface area ensures increased contact which ultimately degrades it between the organic matter and the attached biomass. Ideally, the material must occupy a surface area of 90 to $300 \mathrm{~m}^{2}$ per $\mathrm{m}^{3}$ of the volume of the reactor. The typical filter content sizes vary from 12 to $55 \mathrm{~mm}$ in diameter. Widely used products include dirt, crushed stones or bricks, cinder, pumice, and specially shaped plastic parts, depending on local availability. The systems are used for the secondary treatment of SWW to achieve high solids removal and biogas production. These systems usually work in series and have a fixed bed biological reactor coupled with a filtration chamber. When the SWW flows through the filtration chambers, large and medium suspended particles are confined within; then, the active biomass attached to the surface of the filter degrades the particulate organic matter [9]. Gannoun et al. [43] examined the performance of upflow anaerobic filters (UAFs) treating SWW at mesophilic and thermophilic temperatures. The results showed that at an organic loading rate (OLR) of $9 \mathrm{~g} / \mathrm{L} / \mathrm{d}$, the COD removal efficiency was $90 \%$ at mesophilic, and only $72 \%$ was achieved at the thermophilic condition. On the other hand, the mesophilic $\left(35^{\circ} \mathrm{C}\right)$ treatment of SWW at a high organic loading rate of OLR $10.05 \mathrm{~kg} / \mathrm{m}^{3}$ day and HRT of $12 \mathrm{~h}$ was evaluated by Rajakumar et al. [44]. The system recorded a COD removal rate of $79 \%$ with a varied methane production between 46 and $56 \%$ on the average. The experiment of Stets et al. [45] evaluated the influence of substrate characteristics, microorganisms present in the sludge, and the supporting media in AF. The results showed a maximum COD and TN removal efficiency of 80 and $90 \%$ at an HRT of 1 day. The major drawback of anaerobic baffle reactor is the need for relatively higher temperatures for optimum service, but this is not an obstacle in tropical countries.

\subsubsection{Anaerobic Baffled Reactor}

Anaerobic baffled reactors (ABRs) consist of a series of compartments with inlet and outlet, in which SWW flows in from beneath and above. The reactor is commonly referred to as an optimized version of a septic tank, and the diagrammatic representation of the reactor design and its characteristic dimensions is shown Figure 8. 


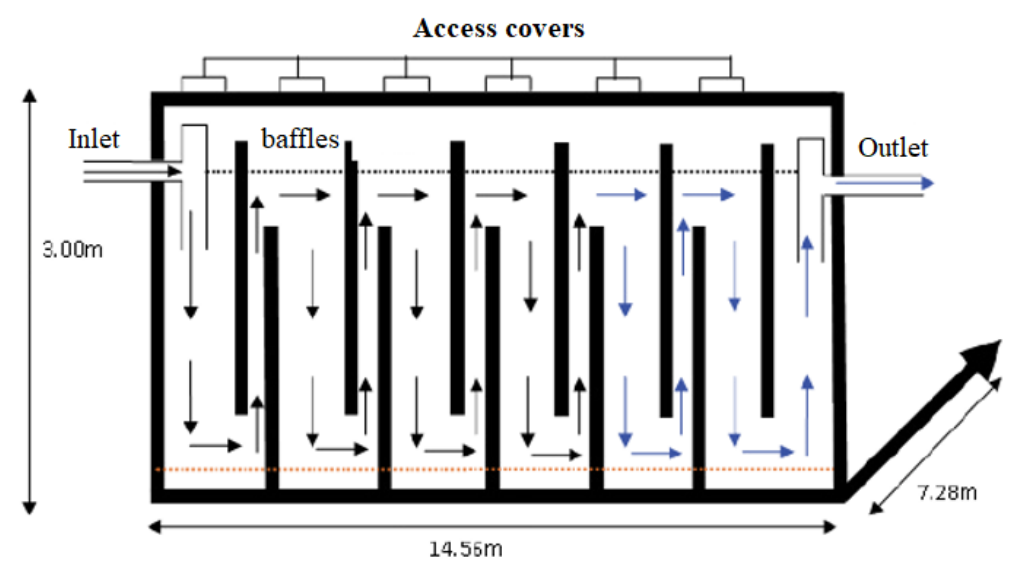

Figure 8. Anaerobic baffled reactor [46].

The purpose of using the anaerobic baffled reactor is to provide the enhanced removal and digestion of organic matter as well as of microorganisms present in the influent. The design objective was to increase the contact time between the suspended or dissolved contaminants and biomass and to minimize the amount of sludge washout in the ABR effluent. This can be achieved by maximizing the hydraulic retention time, the number of passes through the sludge bed (i.e., the number of compartments), and the upflow rate to reduce the transport of solids within processing and capital cost constraints as determined by solid retention. Two six-compartment anaerobic baffled reactors to be installed in series are usually designed to achieve maximum treatment rates. This engineered two six-compartment ABR offers $96 \mathrm{~h}$ ( $48 \mathrm{~h}$ for each $\mathrm{ABR}$ ) hydraulic retention period which by far was higher than the 48-92 h ranges for high peak-flow output levels and the 20-60 h, which allowed high-performance treatment for domestic wastewater. The peak up-flow rate of $0.54 \mathrm{~m} / \mathrm{h}$ was proposed by Foxon and Buckley [47], and peak flow factor of 1.8 resulted in an upflow rate of $0.30 \mathrm{~m} / \mathrm{h}$. This value corresponds to the one suggested by Tilley et al. [42], which is $<0.6 \mathrm{~m} / \mathrm{h}$. The study of Kuşçu and Sponza [48] revealed that a significant improvement in COD and BOD removals up to $90 \%$ was achieved in the upflow compartment. A laboratory-scale study of the performance of combine ABR and UV $/ \mathrm{H}_{2} \mathrm{O}_{2}$ treating SWW with a total organic carbon (TOC) concentration of $973 \mathrm{mg} / \mathrm{L}$ exhibited high organic carbon removal efficiency up to 95\% [49]. One major drawback of this type of reactor is that the system does not have auxiliary mechanisms for the retention of biomass, in the case of large variations and extreme peaks of the influential flow.

\subsubsection{Upflow Anaerobic Sludge Blanket Reactor}

The development of the UASB technology dated back to the late 1970s, and was initially developed for the anaerobic treatment of liquid waste streams with a high concentration of COD (1.0 to $\left.200 \mathrm{~g} \mathrm{COD} \mathrm{L}^{-1}\right)$ and low solid content [50,51]. The upflow anaerobic sludge blanket (UASB) reactor is a tank with a sludge bed occupying half or less the volume of the total tank from the bottom of the tank. UASB reactor consists of three zones: the sludge zone containing the biomass, substrate-like SWW, and the gas zone above the substrate [52,53]. As the name implies, upflow, the SWW enters from the bottom and flows upward with a high or low velocity through the sludge blanket, which then exits from the top as an effluent as illustrated in Figure 9. Depending on the prevailing parameters, literature have reported a satisfactory performance of the UASB reactor in degrading SWW. 


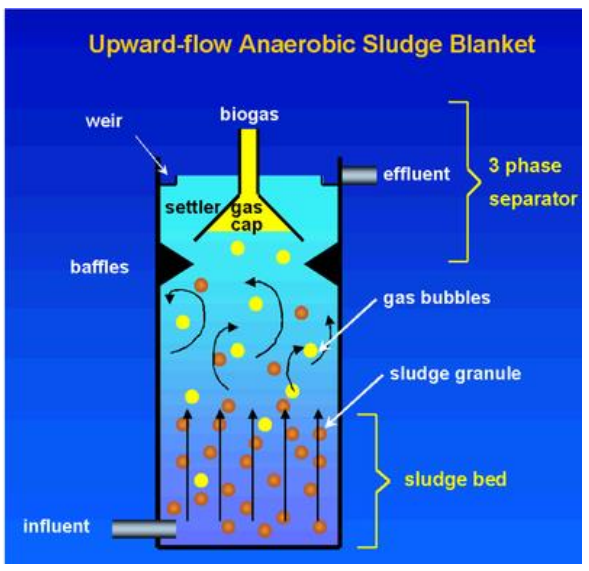

Figure 9. Conceptual diagram of upflow anaerobic sludge blanket (UASB) [54].

The many advantages of UASB reactors include less sludge production, energy recovery, and the overall low cost of application [55]. Moreover, the bacteria can withstand a long period of starvation without dying, and only one discharge of sludge is required per year for a UASB reactor with around $4 \mathrm{~m}$ high. Tropical countries stand to benefit more in the use of the UASB reactor because they work better at mesophilic conditions. The research of Caldera et al. [56] demonstrated that a high COD removal efficiency of up to $94.31 \%$ from a UASB reactor treating SWW under mesophilic condition. The substrate concentration varied from 1820 to $12,790 \mathrm{mg} / \mathrm{L}$, and the experiment lasted for 90 days at HRT of $24 \mathrm{~h}$. In another development, Chávez et al. [57] reported the 95\% BOD removal efficiency of UASB treating slaughterhouse waste at an optimum OLR 31,000 mg/L under mesophilic conditions at HRT 3.5 and $4.5 \mathrm{~h}$. The work of Miranda on the $800 \mathrm{~m}^{3}$ full-scale UASB reactor treating SWW with an influent of COD concentration in the range of $1400-3600 \mathrm{mg} / \mathrm{L}$ and oil and grease content between 413 and $645 \mathrm{mg} / \mathrm{L}$, respectively. The results of their experiment revealed that around $70-92 \%$ COD and $27-58 \%$ oil and grease removal efficiencies. Moreover, an optimum COD removal efficiency of $90 \%$ was also revealed in the study of Rajakumar and Meenambal, [58] at an HRT of $10 \mathrm{~h}$, varying the COD concentration from 3000 to $4800 \mathrm{mg} / \mathrm{L}$ in the UASB reactor. Mijalova et al. [59] analysed the output of a UASB reactor treating SWW after solid separation under the ambient condition. It was reported that the efficiencies of COD removal improved in relation to OLRs. With an influent COD concentration of $3437 \mathrm{mg} / \mathrm{L}$, the system recorded a high COD removal efficiency of $90 \%$. While UASB reactors are found to be effective for SWW treatment, compliance with current water quality standards for water body discharge requires a post-treatment process. Table 2 shows the review of the performance of previous works on UASB reactors treating SWW and other wastewater. However, the system shortfall of sludge washout at elevated upflow velocity and the slow-growing methanogenic bacteria. The performance of various UASB reactors treating slaughterhouse and other wastewaters are shown in Tables 2 and 3. 
Table 2. The performance comparison of different UASB reactor treating slaughterhouse wastewater.

\begin{tabular}{|c|c|c|c|c|c|c|c|c|}
\hline Type of Substrate & OLR & HRT (h) & $\begin{array}{c}\text { Temperature } \\
\left({ }^{\circ} \mathrm{C}\right)\end{array}$ & \%COD Removal & Biogas Production & $\begin{array}{c}\text { SMP } \\
\left(\mathrm{L} \mathrm{g}^{-1} \mathrm{COD}_{\text {added }}\right)\end{array}$ & Scale & Reference \\
\hline $\begin{array}{c}\text { Slaughterhouse } \\
\text { wastewater }\end{array}$ & $\begin{array}{c}0.2-1.4 \\
\mathrm{~kg} \mathrm{COD} / \mathrm{m}^{3} \mathrm{~d}^{-1}\end{array}$ & 12 & $24-35^{\circ} \mathrm{C}$ & $30-62 \%$ & $3.45 \mathrm{~L} / \mathrm{d}$ & NR & $\mathrm{Lab}$ & {$[60]$} \\
\hline $\begin{array}{c}\text { Slaughterhouse } \\
\text { wastewater }\end{array}$ & $\begin{array}{l}1.46 \text { to } 2.43 \mathrm{~kg} \\
\mathrm{COD} / \mathrm{m}^{3} \mathrm{~d}^{-1}\end{array}$ & $18-27$ & $25^{\circ} \mathrm{C}$ & $70-92 \%$ & NR & NR & Full & {$[61]$} \\
\hline $\begin{array}{c}\text { Slaughterhouse } \\
\text { wastewater }\end{array}$ & $\begin{array}{l}0.64-2.95 \mathrm{~kg} \\
\mathrm{COD} / \mathrm{m}^{3} \mathrm{~d}^{-1}\end{array}$ & NR & $35^{\circ} \mathrm{C}$ & $58.4 \%$ & $270 \mathrm{~mL} / \mathrm{d}$ & NR & $\mathrm{Lab}$ & {$[62]$} \\
\hline $\begin{array}{c}\text { Slaughterhouse } \\
\text { wastewater }\end{array}$ & $\begin{array}{c}13-39 \mathrm{~kg} \\
{ }_{\mathrm{s}} \mathrm{COD} / \mathrm{m}^{3} \mathrm{~d}^{-1}\end{array}$ & $2-7$ & $33^{\circ} \mathrm{C}$ & $75-90 \%$ & NR & $\begin{array}{c}200-280 \mathrm{LCH}_{4} / \mathrm{kg} \\
\mathrm{SCOD}_{\text {removed }}\end{array}$ & Pilot & [63] \\
\hline $\begin{array}{l}\text { Slaughterhouse } \\
\text { wastewater }\end{array}$ & $4-15 \mathrm{~kg}$ COD $/ \mathrm{m}^{3} \mathrm{~d}^{-1}$ & $0.88,0.710 .44,0.30$ & $20.9-25^{\circ} \mathrm{C}$ & $90 \%$ & $\begin{array}{c}0.020 \pm 70.013 \\
0.039 \pm 70.010 \\
0.095 \pm 70.008 \mathrm{~m}^{3} / \mathrm{d}\end{array}$ & $\begin{array}{c}0.239 \pm 70.095 \\
0.266 \pm 70.005 \mathrm{~m}^{3} / \mathrm{kg} \\
\text { COD }_{\text {removed }}\end{array}$ & $\mathrm{Lab}$ & [59] \\
\hline $\begin{array}{c}\text { Poultry } \\
\text { slaughterhouse } \\
\text { wastewater }\end{array}$ & $2.1 \mathrm{~kg} \mathrm{COD} / \mathrm{m}^{3} \mathrm{~d}^{-1}$ & $1-5$ & NR & $>80 \%$ & NR & NR & $\mathrm{Lab}$ & [64] \\
\hline $\begin{array}{c}\text { Poultry } \\
\text { slaughterhouse } \\
\text { wastewater }\end{array}$ & $15 \mathrm{~kg} \mathrm{COD} / \mathrm{m}^{3} \mathrm{~d}^{-1}$ & $24,16,12,10$ and 8 & $29-35^{\circ} \mathrm{C}$ & $78 \%$ & $20.3 \mathrm{~L} / \mathrm{d}$ & $\begin{array}{c}0.24 \mathrm{~m}^{3} \mathrm{CH}_{4} / \\
\mathrm{kg} \mathrm{COD} \text { removed }\end{array}$ & $\mathrm{Lab}$ & {$[44]$} \\
\hline $\begin{array}{l}\text { Slaughterhouse } \\
\text { wastewater }\end{array}$ & $\begin{array}{c}0.32,0.51,1.16 \text { and } \\
2.31 \mathrm{~kg} \mathrm{COD} / \mathrm{m}^{3} \mathrm{~d}^{-1}\end{array}$ & $22,14,6$ and 3 & $29.6 \pm 1.40^{\circ} \mathrm{C}$ & $43.39-84.54 \%$ & $143.9 \mathrm{~m}^{3}$ & $\begin{array}{l}0.09 \pm 0.03 \text { to } \\
0.22 \pm 0.02 \mathrm{~m}^{3} / \\
\mathrm{kgCOD} \text { removed }\end{array}$ & Pilot & [66] \\
\hline $\begin{array}{l}\text { Slaughterhouse } \\
\text { wastewater }\end{array}$ & $1.2 \mathrm{~kg} \mathrm{COD} \mathrm{m}^{-3} \mathrm{~d}^{-1}$ & 24 & $30 \pm 1{ }^{\circ} \mathrm{C}$ & $70 \%$ & NR & NR & $\mathrm{Lab}$ & [67] \\
\hline $\begin{array}{l}\text { Slaughterhouse } \\
\text { wastewater }\end{array}$ & 0.54 & 15.6 & $35 \pm 1^{\circ} \mathrm{C}$ & 50.9 & NR & $\begin{array}{c}100 \mathrm{~mL} \\
\mathrm{CH}_{4} / \mathrm{gCOD}_{\text {added }}\end{array}$ & $\mathrm{Lab}$ & [68] \\
\hline
\end{tabular}


Table 3. UASB performances on various types of wastewater.

\begin{tabular}{|c|c|c|c|c|c|c|c|}
\hline Type of Substrate & Temperature & Influent COD & $\begin{array}{c}\text { HRT } \\
\text { (h) }\end{array}$ & $\begin{array}{l}\text { OLR } \\
\text { (d) }\end{array}$ & Biogas Produced & COD Removal (\%) & References \\
\hline Low strength wastewater & $\begin{array}{c}\text { Ambient temperature } \\
\left(20-35^{\circ} \mathrm{C}\right)\end{array}$ & $500 \mathrm{mg} / \mathrm{L}$ & 3 & $4 \mathrm{~kg} \mathrm{COD} / \mathrm{m}^{3} / \mathrm{d}$ & $141 \mathrm{~L} / \mathrm{kg}$ COD removed & $90-92 \%$ & [69] \\
\hline Domestic wastewater & Ambient temperature & - & 7.6 & $1.21 \mathrm{~kg} \mathrm{COD} / \mathrm{m}^{3} / \mathrm{d}$ & $\begin{array}{l}0.34 \mathrm{~m}^{3} \mathrm{CH}_{4} / \\
\text { g COD removed }\end{array}$ & $85 \%$ & {$[70]$} \\
\hline Wheat straw stillage & $55^{\circ} \mathrm{C}$ & $70 \mathrm{~g} / \mathrm{L}$ & 48 & $17.1 \mathrm{~g} \mathrm{COD} / \mathrm{L} / \mathrm{d}$ & $154.8 \mathrm{~mL} \mathrm{CH}_{4} / \mathrm{g} \mathrm{COD}$ & $76 \%$ & [71] \\
\hline $\begin{array}{c}\text { Composite chemical } \\
\text { wastewater }\end{array}$ & $29 \pm 2{ }^{\circ} \mathrm{C}$ & $6600 \mathrm{mg} / \mathrm{L}$ & 37 & $4.25 \mathrm{~kg} \mathrm{COD} / \mathrm{m}^{3} / \mathrm{d}$ & $\begin{array}{c}0.3 \mathrm{~m}^{3} \mathrm{CH}_{4} / \mathrm{kg} \\
\mathrm{COD}_{\text {removed }}\end{array}$ & $62 \%$ & [72] \\
\hline Potato leachate wastewater & $37^{\circ} \mathrm{C}$ & $20 \mathrm{~g} / \mathrm{L}$ & & $6.1 \mathrm{~g} \mathrm{COD} / \mathrm{L} / \mathrm{d}$ & $\begin{array}{c}0.23 \mathrm{~L} \mathrm{CH}_{4} / \\
\mathrm{g} \mathrm{COD}_{\text {degraded }}\end{array}$ & $93 \pm 5.3 \%$ & [73] \\
\hline Seaweed leachate & $37 \pm 1{ }^{\circ} \mathrm{C}$ & $7.3 \pm 1.1 \mathrm{~g} / \mathrm{L}$ & 88.8 & $2.9 \mathrm{~g} \mathrm{COD} / \mathrm{L} / \mathrm{d}$ & $\begin{array}{c}0.23 \pm 0.03 \mathrm{NL} \mathrm{CH}_{4} / \mathrm{g} \\
\mathrm{COD}_{\text {added }}\end{array}$ & - & {$[74]$} \\
\hline $\begin{array}{l}\text { High-strength municipal } \\
\text { wastewater }\end{array}$ & $30^{\circ} \mathrm{C}$ & $1200 \mathrm{mg} / \mathrm{L}$ & 4 & $7.2 \mathrm{~kg} \mathrm{COD} / \mathrm{m}^{3} /$ day & $306.6 \mathrm{~mL} \mathrm{CH}_{4} / \mathrm{g} \mathrm{COD}_{\text {removed }}$ & $85 \%$ & [75] \\
\hline Potato juice & $37^{\circ} \mathrm{C}$ & $25.2 \mathrm{~g} / \mathrm{L}$ & 240 & $2.5 \mathrm{~g} \mathrm{COD} / \mathrm{L} / \mathrm{d}$ & $\begin{array}{c}250 \pm 6 \mathrm{~mL} \mathrm{CH}_{4} / \\
\mathrm{gVS}_{\text {added }}\end{array}$ & - & [76] \\
\hline $\begin{array}{l}\text { High salinity wastewater from } \\
\text { heavy oil production }\end{array}$ & $30 \pm 2{ }^{\circ} \mathrm{C}$ & $350-640 \mathrm{mg} / \mathrm{L}$ & 48 & $0.23 \mathrm{~kg} \mathrm{COD} / \mathrm{m}^{3} / \mathrm{d}$ & - & $65.08 \%$ & [77] \\
\hline Low strength wastewater & $\begin{array}{c}\text { Ambient temperature } \\
\left(24-35^{\circ} \mathrm{C}\right)\end{array}$ & 700-1000 mg/L & - & $1.293 \mathrm{~kg} \mathrm{COD} / \mathrm{m}^{3} / \mathrm{d}$ & $457 \mathrm{~L} / \mathrm{kg}$ COD removal & $90.8 \%$ & {$[78]$} \\
\hline
\end{tabular}


A literature review on the anaerobic digestion process was carried out to identify the main concepts and operating parameters associated with the upflow anaerobic sludge blanket reactors, as the selected technology and the issues relevant to the investigations (Tables 2 and 3). The review summarizes the main findings related to COD removal efficiencies and the biogas production of the UASB reactors treating slaughterhouse and slaughterhouse-related wastewater. A considerable amount of attention was given to the effects of OLR and HRT on the efficiency of the systems which are potentially the key parameters for the digestion of slaughterhouse and other organic wastewater. A laboratory scale study of the anaerobic digestion of slaughterhouse wastewater by Chollom et al. [60] showed 30-62\% COD removal efficiency. It can be seen that, the COD removal efficiency and the biogas production were low. These could be due the low temperature and the HRT. Similarly, Batubara et al. [62], Nacheva et al. [59] and Del Nery et al. [64] studied the anaerobic digestion of slaughterhouse wastewater at the laboratory scale. However, it was observed that the systems were highly characterized by long HRT and low biogas production. On the other hand, a pilot scale investigation showed a high COD removal efficiency $[63,66]$. Conversely, the work of Worku [62] revealed a very low specific methane production (SMP), and this could be attributed to the low COD of the effluent $(\mathrm{COD}=7049.07 \pm 306.42 \mathrm{mg} / \mathrm{L})$.

The application of the UASB reactor achieved considerable success in the treatment of a wide range of other organic industrial effluents including low- and high-strength domestic wastewater as depicted in Table 3. However, the systems were characterized by long HRT, although the study of Singh et al. [69] and Hazrati and Shayegan [75], showed a lower HRT and high COD removal efficiency, but the influent COD concentration was very low as compared to other wastewater presented in Table 3. Therefore, there is the need to modify the UASB reactor to treat high strength wastewater at a higher OLR and short HRT and to also comply with the stringent environment regulations.

\subsubsection{Suspended and Attached Growth Process}

The waste flows through and around free-floating microorganisms in a suspendedgrowth system, such as activated sludge processes (Figure 10A,B) (also aerated lagoons and aerobic digestion), accumulating into biological flocks which then settle out of the wastewater. the influent wastewater characteristics such as (COD), total N, and total P and operating parameters like HRT, SRT, dissolved oxygen (DO), return activated sludge (RAS), and mixed liquor recirculation (MLR) flow rate have significant impacts on the performance of anaerobic, anoxic and aerobic system (Figure 10A). However, the competition for organic substrates among the bacterial population, there is a concern about the adverse effects of the returning sludge on the growth of the bacteria, which prefer to grow under alternating anaerobic and aerobic conditions. Therefore, to overcome the inherent drawbacks of the anaerobic, anoxic and aerobic processes, a reverse anoxic, anaerobic and aerobic process (Figure 10B) is believe to improve the performance of the bacteria through aerobic conditions.

The microbial mass is retained as flocs in suspended growth systems in the mixed liquor of the reactor. Mechanical mixers or gas injection hold these flocs in suspension with agitation. The air in aerobic processes and biogas in anaerobic systems will normally be the latter. Agitation facilitates intimate interaction between the substrate and the biomass. Microbes are attached to the support medium in a thin layer in biofilm systems. The latter can be a static bed or a moving bed. Fixed or stationary beds are usually moulded plastic or gravel shapes, while moving beds may include granular activated carbon or sand grains. These beds of support medium may be submerged in a mixed liqueur during the operation of the reactor or otherwise exposed to the air and wastewater. The bulk of the aerobic systems used in wastewater treatment plants are suspended growth systems. Other examples of suspended growth systems include the aerated lagoon, oxidation ditch, and batch sequencing reactor. However, biofilms with suspended growth can sometimes be integrated into such aerobic systems. Attached growth systems (also known as fixed- 
film processes) are processes for the treatment of biological wastewater with the biomass attached to certain types of media. Figure 11a shows the laboratory scale attached growth system, while Figure $11 \mathrm{~b}$ represents a pilot-scale attached growth system, likewise.
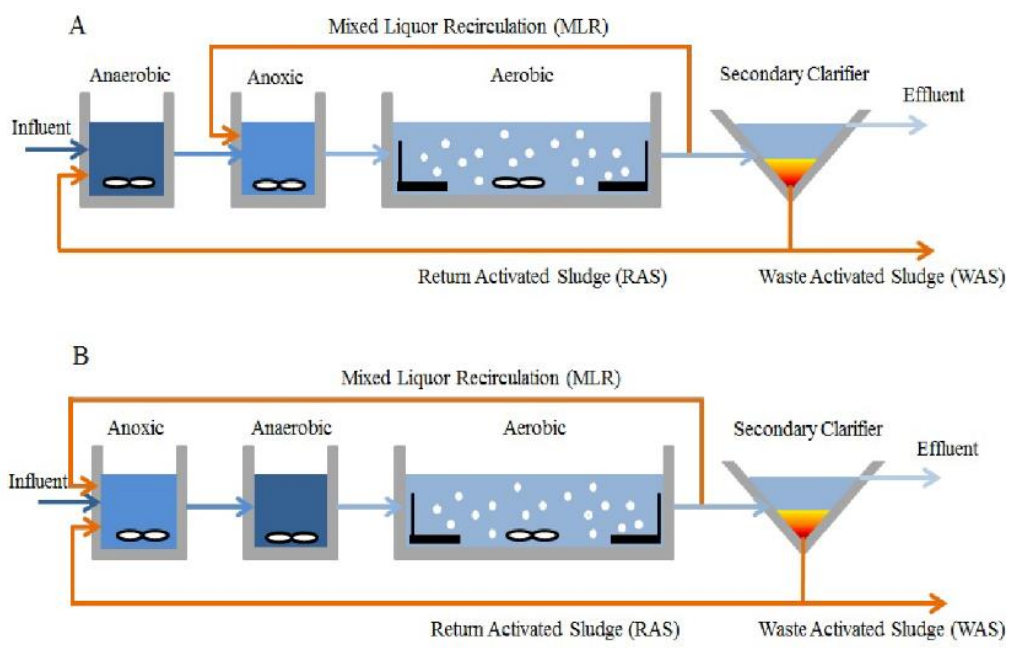

Figure 10. Schematic of two conventional activated sludge processes [79]. It's the same diagram: (A) and (B). The only difference is that the mixed liquor recirculation (MLR) is returned to aerobic condition (A) and sometimes is to return anoxic (B).

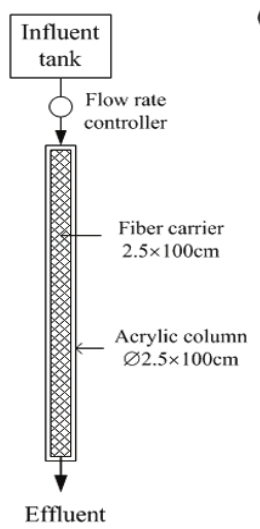

(a)

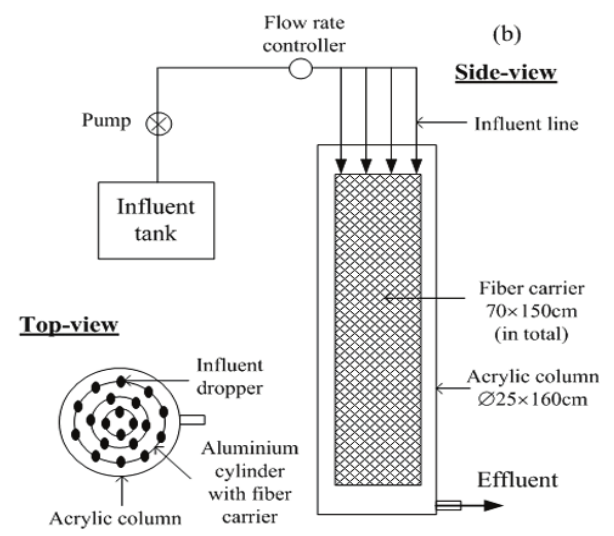

Figure 11. A schematic diagram of attached growth system [80]. Figure represents attached growth system in (a) lab-scale and (b) pilot-scale.

Figure 12 shows the difference between the suspended and the attached growths. The growth formed in the media is a mixture of mainly aerobic microorganisms.

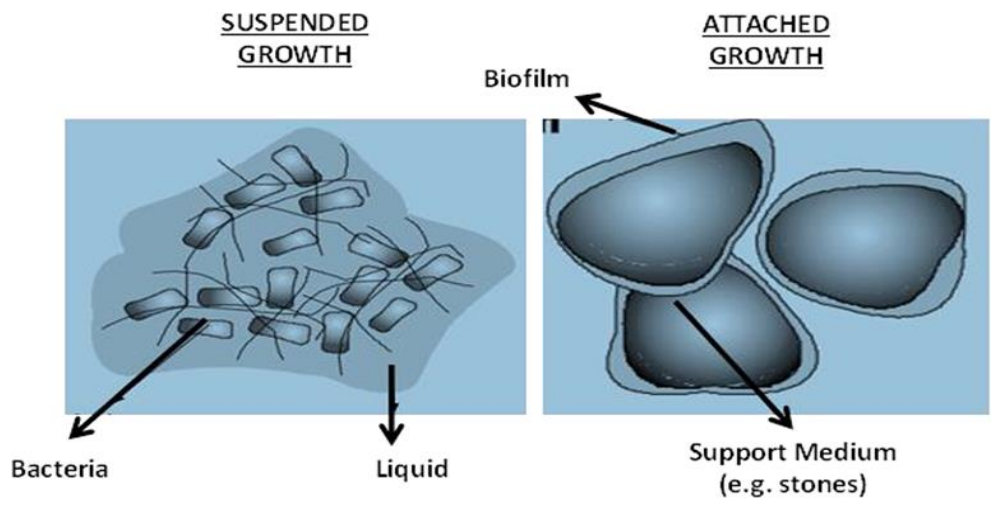

Figure 12. Typical examples of suspended and attached growth system [81]. 
These are similar to those found in other secondary biological treatment processes. The microorganisms include ciliates, rotifers, nematodes, and many others that are freeswimming and stalking. Attached growth processes are easy to operate and resistant to shock loads but are less versatile than activated sludge processes for process control.

\subsubsection{Summary of Biological Treatment Methods}

Table 4 summarizes the advantages and disadvantages of the different physicochemical treatment methods of slaughterhouse wastewater.

Table 4. Advantages and disadvantages of biological treatment methods.

\begin{tabular}{|c|c|c|}
\hline Methods & Advantage & Disadvantage \\
\hline $\begin{array}{l}\text { Anaerobic lagoon } \\
\text { (AL) }\end{array}$ & $\begin{array}{l}\text { - It is the most preferred method of treating } \\
\text { slaughterhouse wastewater (SWW) due to its } \\
\text { simplicity, low cost of operation and } \\
\text { maintenance. } \\
\text { - No mechanical mixing is required. } \\
\text { A typical AL with a depth of } 3-5 \text { m and a } \\
\text { hydraulic retention time (HRT) of } 5-10 \text { days } \\
\text { usually achieve COD, BOD, and TSS removal } \\
\text { efficiency of up to } 96 \%, 97 \% \text { and } 95 \% \text {. } \\
\text { Odour and smell reduction is achieved by } \\
\text { employing synthetic floating cover to collect } \\
\text { biogas and trap the odour. }\end{array}$ & $\begin{array}{l}\text { Depends largely on the climate, location, } \\
\text { availability of land, and proximity to urban } \\
\text { areas. } \\
\text { A layer of scum frequently forms on the } \\
\text { surface. } \\
\text { - Long HRT. } \\
\text { The synthetic cover may experience leakages } \\
\text { with time due to fluctuation in temperature. }\end{array}$ \\
\hline $\begin{array}{c}\text { Anaerobic filters } \\
\text { (AF) }\end{array}$ & $\begin{array}{l}\text { - Have } 3 \text { chambers with filters and the active } \\
\text { biomass attached to the surface of the filter } \\
\text { degrades the particulate organic matter. } \\
\text { Runs in upflow mode, hence mechanical } \\
\text { mixing is not required. }\end{array}$ & $\begin{array}{l}\text { - Relatively high temperature is required. } \\
\text { - } \quad \text { The systems are used for secondary treatment } \\
\text { of SWW to achieve high solids removal and } \\
\text { biogas production. } \\
\text { - The filters can easily clog. }\end{array}$ \\
\hline $\begin{array}{l}\text { Anaerobic baffled } \\
\text { reactor }(\mathrm{ABF})\end{array}$ & $\begin{array}{l}\text { Increases the contact time between suspended } \\
\text { or dissolved contaminants and biomass and } \\
\text { minimizes the amount of sludge washout. }\end{array}$ & $\begin{array}{l}\text { - } \quad \text { Lacks biomass retention mechanism. } \\
\text { - } \quad \text { Long HRT. } \\
\text { Biomass could easily washout at peak flow } \\
\text { and short HRT. }\end{array}$ \\
\hline $\begin{array}{l}\text { Upflow anaerobic } \\
\text { sludge blanket } \\
\text { reactor }\end{array}$ & $\begin{array}{l}\text { - } \quad \text { Less sludge production. } \\
\text { - } \quad \text { Energy and materials recovery. } \\
\text { - } \quad \text { (OLR). } \\
\text { - } \quad \text { Required small reactor volume and space for } \\
\text { installation. } \\
\text { - } \quad \text { Low operation and maintenance cost. }\end{array}$ & $\begin{array}{l}\text { - Long start-up period due to slow growing } \\
\text { methanogenic bacteria. } \\
\text { - } \quad \text { Sludge washout at low HRT. } \\
\text { - } \quad \text { Scum formation on the substrate surface. } \\
\text { - } \quad \text { Effluent post treatment. }\end{array}$ \\
\hline $\begin{array}{l}\text { Suspended growth } \\
\text { (activated sludge } \\
\text { process) }\end{array}$ & $\begin{array}{l}\text { - Commonly applied method for a large volume } \\
\text { of wastewater. } \\
\text { Biomass recirculation simplified the } \\
\text { continuous operation. } \\
\text { - Good effluent quality. }\end{array}$ & $\begin{array}{l}\text { Mainly aerobic bacteria, hence no energy is } \\
\text { - } \quad \text { Require large space. } \\
\text { - } \quad \text { High cost of operation and maintenance. } \\
\text { - } \quad \text { Not flexible (in case of change in waste } \\
\text { concentration). } \\
\text { - Sludge disposal is required on large scale. }\end{array}$ \\
\hline $\begin{array}{l}\text { Attached growth } \\
\text { process }\end{array}$ & $\begin{array}{l}\text { - The attached growth processes are low } \\
\text { maintenance, low energy requirements, and, } \\
\text { overall, less technology involved. } \\
\text { Very effective for biochemical oxygen demand } \\
\text { (BOD) removal, nitrification, and } \\
\text { denitrification }\end{array}$ & $\begin{array}{l}\text { - Mostly suitable for the treatment of } \\
\text { wastewater for small communities. } \\
\text { Larger area requirement, ineffective in cold } \\
\text { weather, and creates odour problems. }\end{array}$ \\
\hline
\end{tabular}




\subsection{Concluding Remarks}

The literature review revealed that anaerobic digestion appeared as a promising technology for the treatment of low- and high-strength slaughterhouse wastewater, although it is a complex and sensitive process. The operation of the anaerobic reactor is highly dependent on the temperature, $\mathrm{pH}$, hydraulic retention time, and loading rates as well as wastewater and biomass characteristics. It was also found that, for good substrate degradation, anaerobic reactors' optimal temperature conditions include psychrophilic $\left(<25^{\circ} \mathrm{C}\right)$, mesophilic $\left(25-40^{\circ} \mathrm{C}\right)$ and thermophilic $\left(>45^{\circ} \mathrm{C}\right)$. However, most of the studies showed that the reactor performance was more stable at mesophilic condition $\left(25-40{ }^{\circ} \mathrm{C}\right)$. Likewise, stable $\mathrm{pH}$ condition usually exists between 6.5 and 7.5. Among the various anaerobic reactors, UASB reactor showed high biogas production and COD removal efficiency at high OLR. The system is also characterized by low sludge production compared to other physicochemical treatment methods, where less energy is applied and high energy is generated and the overall cost of operation and maintenance is lower. While conventional UASB reactors appear to be a promising choice for the recovery of energy from organic wastewater, including slaughterhouse wastewater (SWW), there are potential problems associated with the reactor. These include the long start-up period due to the slowly growing microorganism, sludge washout at low HRT, scum formation on the substrate surface - especially in in the treatment of SWW-and the suspended solid accumulation at high inflow velocity with low HRT.

Several researchers have studied the role of attached growth media in increasing the concentration of the microbial population. However, most of the systems were highly characterized by long HRT and low OLR especially in conventional UASB reactors (Table 2). Furthermore, most of the media used for microbial attachment in anaerobic reactors are usually made of plastic materials with a smooth surface and normally configured in suspended moving media, which leads to the overflow of the media on the substrate surface during influent pumping at higher velocity and these consequently result in insufficient contact between the microbes and the media. Additionally, as a result of the separation between microbes and the media, the microbes could easily washout during effluent discharge. Despite the numerous studies on this subject, none of the previous research has focused on the comparison between the performance of the conventional UASB reactor and UASB reactor with fixed attached growth media with a rough and large surface area that confines the whole sludge zone in a UASB reactor treating high strength cattle slaughterhouse wastewater (CSWW). The literature review has thus identified some key gaps in the knowledge, especially in aerobic and anaerobic treatment processes, and indicated a number of concepts and tools that may be useful in future research. For instance, aerobic processes are highly characterized by high energy demand, the large area of land for installation, huge quantity of sludge production and inefficient small and medium scale industries. Similarly, most anaerobic systems required a long HRT for bacterial growth, and sludge easily washes out along with the large microbial population during effluent discharge and is highly temperature dependent. Therefore, further research on the use of organic or inorganic waste materials or cellulose materials should be conducted to further harness the most cost-effective methods of slaughterhouse wastewater treatment.

Author Contributions: Conceptualization, M.A.M. and S.I.; methodology, M.A.M.; validation, S.I.; formal analysis, M.A.M.; investigation, M.A.M.; resources, S.I.; data curation, S.I.; writing-original draft preparation, M.A.M.; writing-review and editing, S.I.; visualization, S.I.; supervision, S.I. All authors have read and agreed to the published version of the manuscript.

Funding: This research was financially supported by the Ministry of Higher Education Malaysia through Fundamental Research Grant Scheme (FRGS/2/2014/TK02/UPM/02/6) and Tenaga Nasional Berhad Research Sdn. Bhd. through Industrial grant (TNBR/Biogas/2019/UPM/6380035).

Institutional Review Board Statement: Not applicable.

Informed Consent Statement: Not applicable. 


\section{Data Availability Statement: Not applicable.}

Acknowledgments: The authors acknowledge the support received from Ministry of Higher Education Malaysia. Also, Tenaga Nasional Berhad Research Sdn. Bhd and the Universiti Putra Malaysia, for the preparation, execution, and writing of this article.

Conflicts of Interest: The authors declare no conflict of interest.

\section{References}

1. Barrera, M.; Mehrvar, M.; Gilbride, K.; McCarthyc, L.H.; Laursen, A.E.; Bostan, V.; Pushchakd, R. Photolytic treatment of organic constituents and bacterial pathogens in secondary effluent of synthetic slaughterhouse wastewater. Chem. Eng. Res. Des. 2012, 90, 1335-1350. [CrossRef]

2. Adami, L.; Schiavon, M. From Circular Economy to Circular Ecology: A Review on the Solution of Environmental Problems through Circular Waste Management Approaches. Sustainability 2021, 13, 925. [CrossRef]

3. Jayathilakan, K.; Sultana, K.; Radhakrishna, K.; Bawa, A.S. Utilization of byproducts and waste materials from meat, poultry and fish processing industries: A review. Food Sci. Technol. 2012, 49, 278-293. [CrossRef] [PubMed]

4. Bhatia, R.K.; Sakhuja, D.; Mundhe, S.; Walia, A. Renewable Energy Products through Bioremediation of Wastewater. Sustainability 2020, 12, 7501. [CrossRef]

5. De Nardi, I.R.; Del Nery, V.; Amorim, A.K.B.; Dos Santos, N.G.; Chimenes, F. Performances of SBR, chemical-DAF and UV disinfection for poultry slaughterhouse wastewater reclamation. Desalination 2011, 269, 184-189. [CrossRef]

6. Al-Mutairi, N.Z.; Al-Sharifi, F.A.; Al-Shammari, S.B. Evaluation study of a slaughterhouse wastewater treatment plant including contact-assisted activated sludge and DAF. Desalination 2008, 225, 167-175. [CrossRef]

7. APHA. Standard Methods for the Examination of Water and Wastewater, 21st ed.; American Public Health Association/American Water Works Association/Water Environment Federation: Denver, CO, USA, 2005.

8. Hubbe, M.A.; Metts, J.R.; Hermosilla, D.; Blanco, M.A.; Yerushalmi, L.; Haghighat, F.; Lindholm-Lehto, P.; Khodaparast, Z.; Kamali, M.; Elliott, A. Haghighat, Wastewater treatment and reclamation: A review of pulp and paper industry practices and opportunities. BioResources 2016, 11, 7953-8091. [CrossRef]

9. Mittal, G.S. Treatment of wastewater from abattoirs before land application A review. Bioresour. Technol. 2006, 97, 1119-1135. [CrossRef]

10. Kiepper, B. A survey of wastewater treatment practices in the broiler industry. Water Environ. Fed. 2001, 12, 12-25. [CrossRef]

11. De Sena, R.F.; Moreira, R.F.P.M.; José, H.J. Comparison of coagulants and coagulation aids for treatment of meat processing wastewater by column flotation. Bioresour. Technol. 2008, 99, 8221-8225. [CrossRef]

12. Teh, C.Y.; Budiman, P.M.; Shak, K.P.Y.; Wu, T.Y. Recent Advancement of Coagulation-Flocculation and Its Application in Wastewater Treatment. Ind. Eng. Chem. Res. 2016, 55, 4363-4389. [CrossRef]

13. Satyanarayan, S.; Ramakant; Vanerkar, A.P. Conventional approach for abattoir wastewater treatment. Environ. Technol. 2010, 26, 441-447. [CrossRef] [PubMed]

14. Tariq, M.; Ahmad, M.; Siddique, S.; Waheed, A.; Shafiq, T.; Khan, M.H. Optimization of coagulation process for the treatment of the characterized slaughterhouse wastewater. Pak. J. Sci. Ind. Res. 2012, 55, 43-48.

15. Emamjomeh, M.M.; Sivakumar, M. Review of pollutants removed by electrocoagulation and electrocoagulation/flotation processes. J. Environ. Manag. 2009, 90, 1663-1679. [CrossRef]

16. Bayar, S.; Yildiz, Y.S.; Yilmaz, A.E.; Irdemez, S. The effect of stirring speed and current density on removal efficiency of poultry slaughterhouse wastewater by electrocoagulation method. Desalination 2011, 280, 103-107. [CrossRef]

17. Bayramoglu, M.; Kobya, M.; Eyvaz, M.; Senturk, E. Technical and economic analysis of electrocoagulation for the treatment of poultry slaughterhouse wastewater. Sep. Purif. Technol. 2006, 51, 4-408. [CrossRef]

18. Kobya, M.; Senturk, E.; Bayramoglu, M. Treatment of poultry slaughterhouse wastewaters by electrocoagulation. J. Hazard. Mater. 2006, 133, 172-176. [CrossRef] [PubMed]

19. Bayar, S.; Yildiz, Y.Ş.; Yilmaz, A.E.; Koparal, A.S. The effect of initial pH on treatment of poultry slaughterhouse wastewater by electrocoagulation method. Desalin. Water Treat. 2014, 52, 3047-3053. [CrossRef]

20. Ozyonar, F.; Karagozoglu, B. Investigation of technical and economic analysis of electrocoagulation process for the treatment of great and small cattle slaughterhouse wastewater. Desalin. Water Treat. 2014, 52, 74-87. [CrossRef]

21. Pérez-Sicairos, S.; Morales-Cuevas, J.B.; Félix-Navarro, R.M.; Hernández-Calderón, O.M. Evaluación del proceso de electrocoagulacíon para la remoción de turbidez de agua de río, agua residual y agua de estanque. Rev. Mex. Ing. Qum. 2011, 10, 79-91.

22. Picard, T.; Cathalifaud-Feuillade, G.; Mazet, M.; Vandensteendam, C. Cathodic dissolution in the electrocoagulation process using aluminium electrodes. J. Environ. Monit. 2000, 2, 77-80. [CrossRef] [PubMed]

23. Gürses, A.; Yalçin, M.; Doar, C. Electrocoagulation of some reactive dyes: A statistical investigation of some electrochemical variables. Waste Manag. 2002, 22, 491-499. [CrossRef]

24. Almandoz, M.C.; Pagliero, C.L.; Ochoa, N.A.; Marchese, J. Composite ceramic membranes from natural aluminosilicates for microfiltration applications. Ceram. Int. 2015, 41, 5621-5633. [CrossRef] 
25. Bohdziewicz, J.; Sroka, E. Integrated system of activated sludge-reverse osmosis in the treatment of the wastewater from the meat industry. Process Biochem. 2005, 40, 1517-1523. [CrossRef]

26. Yordanov, D. Preliminary study of the efficiency of ultrafiltration treatment of poultry slaughterhouse wastewater. Bulg. J. Agric. Sci. 2010, 16, 700-704.

27. Rezakazemi, M.; Khajeh, A.; Mesbah, M. Membrane filtration of wastewater from gas and oil production. Environ. Chem. Lett. 2018, 16, 367-388. [CrossRef]

28. Gürel, L.; Büyükgüngör, H. Treatment of slaughterhouse plant wastewater by using a membrane bioreactor. Water Sci. Technol. 2011, 64, 214-219. [CrossRef]

29. Umaiyakunjaram, R.; Shanmugam, P. Study on submerged anaerobic membrane bioreactor (SAMBR) treating high suspended solids raw tannery wastewater for biogas production. Bioresour. Technol. 2016, 216, 785-792. [CrossRef]

30. Hu, A.Y.; Stuckey, D.C. Treatment of dilute wastewaters using a novel submerged anaerobic membrane bioreactor. J. Environ. Eng. 2006, 132, 190-198. [CrossRef]

31. Dereli, R.K.; Heffernan, B.; Grelot, A.; Van Der Zee, F.P.; Van Lier, J.B. Influence of high lipid containing wastewater on filtration performance and fouling in AnMBRs operated at different solids retention times. Sep. Purif. Technol. 2015, 139, 43-52. [CrossRef]

32. Pierson, J.A.; Pavlostathis, S.G. Real-Time Monitoring and Control of Sequencing Batch Reactors for Secondary Treatment of a Poultry Processing Wastewater. Water Environ. Res. 2000, 72, 585-592. [CrossRef]

33. Martineza, S.L.; Torrettab, V.; Minguelac, J.V.; Siñerizd, F.; Rabonib, M.; Copellib, S.; Cristina Radae, E.; Ragazzie, M. Treatment of slaughterhouse wastewaters using anaerobic filters. Environ. Technol. 2014, 35, 322-332. [CrossRef]

34. Massé, D.I.; Masse, L. Characterization of wastewater from hog slaughterhouses in Eastern Canada and evaluation of their in-plant wastewater treatment systems. Can. Biosyst. Eng. Genie Biosyst. Can. 2000, 42, 139-146.

35. Fu, Y.; Luo, T.; Mei, Z.; Li, J.; Qiu, K.; Ge, Y. Dry Anaerobic Digestion Technologies for Agricultural Straw and Acceptability in China. Sustainability 2018, 10, 4588. [CrossRef]

36. Kim, K.Y.; Yang, W.; Ye, Y.; LaBarge, N.; Logan, B.E. Performance of anaerobic fluidized membrane bioreactors using effluents of microbial fuel cells treating domestic wastewater. Bioresour. Technol. 2016, 208, 58-63. [CrossRef]

37. Awe, O.W.; Zhao, Y.; Nzihou, A.; Minh, D.P.; Lyczko, N. A Review of Biogas Utilisation, Purification and Upgrading Technologies. Waste Biomass Valorization 2017, 8, 267-283. [CrossRef]

38. Wu, P.F.; Mittal, G.S. Characterization of provincially inspected slaughterhouse wastewater in Ontario, Canada. Can. Biosyst. Eng. Genie Biosyst. Can. 2012, 54, 9-18. [CrossRef]

39. McCabe, B.K.; Hamawand, I.; Harris, P.; Baillie, C.; Yusaf, T. A case study for biogas generation from covered anaerobic ponds treating abattoir wastewater: Investigation of pond performance and potential biogas production. Appl. Energy 2014, 114, 798-808. [CrossRef]

40. Ewemoje, O.; Sangodoyin, A. Developing a pilot scale horizontal sub surface flow constructed wetlands for phytoremediation of primary lagoon effluents. In 11th Edition of the World Wide Workshop for Young Environmental Scientists (WWW-YES-2011) - Urban Waters: Resource or Risks? CCSD: Arcueil, France, 2011.

41. Covered Anaerobic Lagoons Meat Industry Applications; Australian Meat Processor Corporation: North Sydney, Austrlia, 2017; pp. $1-8$.

42. Tilley, E.; Ulrich, L.; Luethi, C.; Reymond, P.; Zurburegg, C.; Lüthi, C.M.; Antoine, Z.C.; Schertenleib, R. Compendium of Sanitation Systems and Technologies; Swiss Federal Institute of Aquatic Science and technology (Eawag): Dübendorf, Switzerland, 2014.

43. Gannoun, H.; Bouallagui, H.; Okbi, A.; Sayadi, S.; Hamdi, M. Mesophilic and thermophilic anaerobic digestion of biologically pretreated abattoir wastewaters in an upflow anaerobic filter. J. Hazard. Mater. 2009, 170, 263-271. [CrossRef] [PubMed]

44. Rajakumar, R.; Meenambal, T.; Banu, J.R.; Yeom, I.T. Treatment of poultry slaughterhouse wastewater in upflow anaerobic filter under low upflow velocity. Int. J. Environ. Sci. Technol. 2011, 8, 149-158. [CrossRef]

45. Stets, M.I.; Etto, R.M.; Galvão, C.W.; Ayub, R.A.; Cruz, L.M.; Steffens, M.B.R.; Barana, A.C. Microbial community and performance of slaughterhouse wastewater treatment filters. Genet. Mol. Res. 2014, 13, 4444-4455. [CrossRef] [PubMed]

46. Ndibnuh, P.A.S.; David, N.Y.; Ilorme, F. Conceptual Design of a Decentralized Wastewater Treatment System for the Bamenda Regional Hospital Cameroon. J. Pollut. 2018, 1, 1-11.

47. Foxon, F.M.; Buckley, C.A. Guidelines for the Implementation of Anaerobic Baffled Reactors for On-Site or Decentralized Sanitation; University of Kwazulu Natal: Glenwood, Durban, 2006.

48. Kuşçu, Ö.S.; Sponza, D.T. Performance of anaerobic baffled reactor (ABR) treating synthetic wastewater containing p-nitrophenol. Enzyme Microb. Technol. 2005, 36, 888-895. [CrossRef]

49. Cao, W.; Mehrvar, M. Slaughterhouse wastewater treatment by combined anaerobic baffled reactor and $\mathrm{UV} / \mathrm{H}_{2} \mathrm{O}_{2}$ processes. Chem. Eng. Res. Des. 2011, 89, 1136-1143. [CrossRef]

50. Lettinga, G.; van Velsen, A.F.M.; Hobma, S.W.; De Zeeuw, W.; Klapwijk, A. Use of the upflow sludge blanket (USB) reactor concept for biological wastewater treatment. Biotechnol. Bioeng. 1980, 22, 699-734. [CrossRef]

51. Rajeshwari, K.V.; Balakrishnan, M.; Kansal, A.; Lata, K.; Kishore, V.V.N. State-of-the-art of anaerobic digestion technology for industrial wastewater treatment. Renew. Sustain. Energy 2000, 4, 135-156. [CrossRef]

52. Amorim, A.K.B.; De Nardi, I.R.; Del Nery, V. Water conservation and effluent minimization: Case study of a poultry slaughterhouse. Resour. Conserv. Recycl. 2007, 51, 93-100. [CrossRef] 
53. Del Nery, V.; Pozzi, E.; Damianovic, M.H.R.Z.; Domingues, M.R.; Zaiat, M. Granules characteristics in the vertical profile of a full-scale upflow anaerobic sludge blanket reactor treating poultry slaughterhouse wastewater. Bioresour. Technol. 2008, 99, 2018-2024. [CrossRef]

54. Upflow Anaerobic Sludge Blanket. Available online: microbewiki.kenyon.edu (accessed on 2 November 2020).

55. Daud, M.K.; Rizvi, H.; Akram, M.F.; Ali, S.; Rizwan, M.; Nafees, M.; Jin, Z.S. Review of upflow anaerobic sludge blanket reactor technology: Effect of different parameters and developments for domestic wastewater treatment. Hindawi 2018, $2018,1-13$. [CrossRef]

56. Caldera, E.Y.; Madue, P.; Griborio, A.; Fernandez, G.N. Effect of the organic load in the performance the UASB reactor treating slaughterhouse effluent. Rev. Tec. Fac. Ing. Univ. Zulia 2005, 28, 119-127.

57. Chávez, C.P.; Castillo, R.L.; Dendooven, L.; Escamilla-Silva, E.M. Poultry slaughter wastewater treatment with an up-flow anaerobic sludge blanket (UASB) reactor. Bioresour. Technol. 2005, 96, 1730-1736. [CrossRef]

58. Rajakumar, R.; Meenambal, T. Comparative study on start-up performance of HUASB and AF reactors treating poultry slaughterhouse wastewater. Int. J. Environ. Res. 2008, 2, 401-410.

59. Mijalova Nacheva, P.; Reyes Pantoja, M.; Lomelí Serrano, E.A. Treatment of slaughterhouse wastewater in upflow anaerobic sludge blanket reactor. Water Sci. Technol. 2011, 41, 181-185.

60. Chollom, M.N.; Rathilal, S.; Swalaha, F.M.; Bakare, B.F.; Tetteh, E.K. Study of the start-up of an upflow laboratory-scale anaerobic sludge blanket for the treatment of slaughterhouse wastewater. WIT Trans. Ecol. Environ. 2017, 216, $123-130$.

61. Miranda, L.A.S.; Henriques, J.A.P.; Monteggia, L.O. A full-scale uasb reactor for treatment of pig and cattle slaughterhouse wastewater with a high oil and grease content. Braz. J. Chem. Eng. 2005, 22, 307. [CrossRef]

62. Batubara, F.; Ritonga, N.A.; Turmuzi, M. Start-Up of Upflow Anaerobic Sludge Blanket (UASB) Reactor Treating Slaughterhouse Wastewater. J. Phys. Conf. Ser. 2018, 1116, 042008. [CrossRef]

63. Torkian, A.; Eqbali, A.; Hashemian, S.J. The effect of organic loading rate on the performance of UASB reactor treating slaughterhouse effluent. Resour. Conserv. Recycl. 2003, 40,1-11. [CrossRef]

64. Del Nery, V.; Damianovic, M.H.Z.; Barros, F.G. The use of upflow anaerobic sludge blanket reactors in the treatment of poultry slaughterhouse wastewater. Water Sci. Technol. 2001, 44, 83-88. [CrossRef] [PubMed]

65. Borja, R.; Banks, C.J.; Wang, Z. Performance and kinetics of an upflow anaerobic sludge blanket (UASB) reactor treating slaughterhouse wastewater. J. Environ. Sci. Heal. Part A Environ. Sci. Eng. Toxicol. 1994, 29, 2063-2085. [CrossRef]

66. Worku, Z. Anaerobic Digestion of Slaughterhouse Wastewater for Methane Recovery and Treatability. Int. J. Sustain. Green Energy 2017, 6, 84. [CrossRef]

67. Manjunath, N.T.; Mehrotra, I.; Mathur, R.P. Treatment of wastewater from slaughterhouse by DAF-UASB system. Water Res. 2000, 34, 1930-1936. [CrossRef]

68. Conly, L.H.; Gregery, T.W. Anaerobic digestion of rendering waste in an upflow anaerobic sludge blanket digester. Bioresour. Technol. 1992, 21, 563-567.

69. Singh, K.S.; Harada, H.; Viraraghavan, T. Low-strength wastewater treatment by a UASB reactor. Bioresour. Technol. 1996, 55, 187-194. [CrossRef]

70. Behling, E.; Diaz, A.; Colina, G.; Herrera, M.; Gutierrez, E.; Chacin, E.; Fernandez, N.; Forster, C.F. Domestic wastewater treatment using a UASB reactor. Bioresour. Technol. 1997, 61, 239-245. [CrossRef]

71. Kaparaju, P.; Serrano, M.; Angelidaki, I. Optimization of biogas production from wheat straw stillage in UASB reactor. Appl. Energy 2010, 87, 3779-3783. [CrossRef]

72. Venkata Mohan, S.; Krishna Prasad, K.; Chandrasekhara Rao, N.; Vijaya Bhaskar, Y.; Lalit Babu, V.; Rajagopal, D.; Sarma, P.N. Biological treatment of low-biodegradable composite chemical wastewater using upflow anaerobic sludge blanket (UASB) reactor: Process monitoring. J. Sci. Ind. Res. 2005, 64, 771-777.

73. Parawira, W.; Murto, M.; Zvauya, R.; Mattiasson, B. Comparative performance of a UASB reactor and an anaerobic packed-bed reactor when treating potato waste leachate. Renew. Energy 2006, 31, 893-903. [CrossRef]

74. Nkemka, V.N.; Murto, M. Evaluation of biogas production from seaweed in batch tests and in UASB reactors combined with the removal of heavy metals. J. Environ. Manag. 2010, 91, 1573-1579. [CrossRef] [PubMed]

75. Hazrati, H.; Shayegan, J. Optimizing OLR and HRT in a UASB reactor for pretreating high-Strength municipal wastewater. Chem. Eng. Trans. 2011, 24, 1285-1290.

76. Fang, C.; Boe, K.; Angelidaki, I. Biogas production from potato-juice, a by-product from potato-starch processing, in upflow anaerobic sludge blanket (UASB) and expanded granular sludge bed (EGSB) reactors. Bioresour. Technol. 2011, 102, 5734-5741. [CrossRef] [PubMed]

77. Chunshuang, L.; Dongfeng, Z.; Yadong, G.; Chaocheng, Z. Performance and Modeling of an Up-flow Anaerobic Sludge Blanket (UASB) Reactor for Treating High Salinity Wastewater from Heavy Oil Production. China Pet. Process. Petrochem. Technol. 2012, 14, 90-95.

78. Venkatesh, K.R.; Rajendran, M.; Murugappan, A. Start-Up Of An Upflow Anaerobic Sludge Blanket Reactor Treating Low-Strength Wastewater Inoculated With Non-Granular Sludge. Int. Ref. J. Eng. Sci. 2013, 2, 46-53.

79. $\mathrm{Xu}, \mathrm{S}$. Process Improvements in Biological Nutrient Removal Systems for Better Wastewater Treatment Process Improvements in Biological Nutrient Removal Systems for Better Wastewater Treatment. Ph.D. Thesis, University of Missouri, Columbia, MO, USA, 2014. 
80. Roshan, D.J.M.; Raj, S. Attached growth system for $\mathrm{NH}_{4}-\mathrm{N}$ Removal from groundwater in the kathmandu valley. In Kathmandu Valley Groundwater Outlook; Shrestha, S., Pradhananga, D., Pandey, V.P., Eds.; Asian Institute of Technology (AIT): Klong Luang, Thailand, 2012; pp. 64-68.

81. Sehar, S.; Naz, I. Role of the Biofilms in Wastewater Treatment. In Microbial Biofilms Importance and Applications; IntechOpen Limited: Winchester, UK, 2016; p. 122. 